its functions could be dropped altogether, but that is an invidious position in which to be discovered. Even the environment council's detractors will agree that it is grossly unfair that a public corporation managed by people who are not even civil servants should be saddled with impossible responsibilities and an inadequate budget and invited to make decisions which are, in essence, political. Whether and on what scale there should be a continuing geological survey in Britain is a decision that constitutionally should be made by ministers, not by research council employees or, still less, by volunteer members of advisory committees such as the Advisory Board for the Research Councils. For the time being, the research council's duty is to tell them so, in terms that cannot be shirked. Doing so would necessarily invite attention to the research council's own plight, as it would become if the British Geological Survey were to join the British Antarctic Survey as a protected pensioner of the "protected" British science budget. Ministerial inquirers might well conclude that for the research council, dismemberment would certainly then be the best policy. People are naturally shy of opening that can of worms, but, in propriety, there is no choice.

\section{Star wars bargain}

\section{The US president's science adviser should learn} to temper his loyalty with proper embarrassment.

EVEN under the best of circumstances, one of the essential requirements for the job of science adviser to the US president is a split personality. The scientific community sees the science adviser as a superlobbyist for science - but he is a lobbyist who is also part of the political apparatus, which makes for strain when the apparatus takes decisions not necessarily in the best interests of science. A tight budget is the acid test. Dr George Keyworth's predecessor was able to retain sufficient aloofness from the land of make-believe of Washington politics to appear embarrassed, at least, when forced during the 1980 election to make a series of budgetary about-turns by President Carter seem to be a sudden large new investment in research and development. Keyworth, however, is another matter. He has never made any bones about his conviction that his primary job is to support the president. Keyworth has shown no trace of embarrassment about star wars in the past two years and, last week, in announcing how the 1986 budget will affect science, he showed no embarrassment in playing a little fast and loose with the figures to make it look better than it was. Among his more incorrect statements was that "funds obligated for non-defense research and development will remain essentially constant from 1985 to 1986 ". The budget documents disagree: they show a 4 per cent cut in non-defence research and development and that on top of a 4 per cent or so inflation rate. It is hard to see how an 8 per cent real cut in spending is "essentially" no change.

Keyworth played a more standard Washington game, though one that is no more defensible, in claiming that funds for alternatives to the UNESCO science programmes (see p.518) were to be found in the budgets for various US science agencies. In fact, there is no new money at all except for $\$ 2.7$ million allowed by the State Department (a far cry from the $\$ 50$ million that the United States had been contributing to UNESCO and even from the $\$ 14$ million that the National Academy of Sciences recommended be provided for science activities to make up for the US withdrawal). And while it is true that the National Science Foundation supports a relatively large amount of international cooperative research, this has been going on for years and has nothing to do with UNESCO or the decision to withdraw therefrom. And in any case, international programmes have been cut in the foundation's budget as now proposed. The same game was played in claiming the existence of $\$ 42$ million in the Department of Agriculture's Cooperative State Research Service (CSRS) for biotechnology. This is not new money; the CSRS budget has been frozen.

In testimony before the House of Representatives' Science and Technology Committee last week, Keyworth also glibly defended the administration decision to cut federal assistance to students, noting that parents are demonstrating a new sense of responsibility to educate their children. He has defended the budget's indifference to US-Soviet scientific exchanges, saying, in response to a congressman's admonition to keep an open mind on the subject, that "I' $m$ not sure that I would want to have a terribly open mind in dealing with a country that has an inherently adversarial form of government". He defended the administration request of $\$ 3,700$ million for star wars: "The Soviets have more than one reason to worry about SDI [the Strategic Defense Initiative] in addition to the prospect that strategic defense will make worthless the bulk of their immense offensive nuclear force. Our effort to produce a defensive system will almost certainly stimulate a new thrust in technology and leave the stagnating Soviet economy further behind."

Keyworth summed up by saying, "I'm proud of the budget". It would have been reassuring to the scientific community if he had at least looked a bit embarrassed when he said it.

\section{Loyal Keyworth}

The United States cannot expect next month's Geneva talks to succeed without a bargain.

MR Caspar Weinberger's swing through Western Europe earlier this week is the most serious attempt so far by the US administration to win support for star wars, otherwise the Strategic Defense Initiative (SDI). Chancellor Helmut Kohl in West Germany is Mr Weinberger's most conspicuous convert so far, although the visit of Mrs Margaret Thatcher, the British prime minister, to Washington at the end of last year leaves her on record as having won from President Reagan an assurance that SDI is at this stage strictly a research programme, one that will not be turned into a working military system without consultations on the subject with the Soviet Union. Mr Weinberger might tactfully have made more of this important concession in his declarations at the weekend, especially because much of Western Europe is fearful that the talks arranged for Geneva on 12 March between the Soviet Union and the United States will collapse in the warm glow of the belief engendered by President Reagan's inaugural speech that all is well in the West. Neither Mr Weinberger nor the US administration seems to appreciate that the pursuit of SDI requires some kind of tacit licence from the Soviet Union, at least if the arms control negotiations are to survive.

If SDI is indeed a research programme, the following considerations apply. First, it is by no means certain that the outcome will be a workable defence against strategic missiles. Indeed, there are many who insist that the opposite must be the case, and that the only conceivable outcome of the efforts now being expended will be a kind of improved version of the anti-ballistic missile systems canvassed in the early 1970s and rejected then on the grounds that they would be ruinously expensive and strategically destabilizing. So neither the United States nor, for that matter, West Germany, should count on success, which means that the need for an agreement (if attainable) at Geneva is as urgent as it was before SDI became fashionable. Second, then, it follows that there should be some demonstration at Geneva that SDI is indeed pure exploration, for which purpose the most convenient instrument would be a moratorium (say, for the next four years of the present administration) on the testing of anti-satellite weapons. The case, repeated last week by $\mathrm{Mr}$ Weinberger, that the Soviet Union has already deployed such a weapons system is unconvincing, for it is too primitive a system to be taken seriously at this stage. Third, there is the problem of the anti-ballistic missile treaty, which formally prohibits the development and testing of components of such a system beyond the atmosphere. No doubt there are lawyers who will argue that the bits and pieces that will be developed as part of SDI are not components of an anti-ballistic missile system, for such a device has not yet been designed. But there are lawyers, many of them from the Soviet Union, who will argue the other way. The only way of finessing that difficulty is to have it openly discussed at Geneva. 